\title{
CAPACIDAD PRODUCTIVA DE PLEUROTUS OSTREATUS UTILIZANDO ALFALFA DESHIDRATADA COMO SUPLEMENTO EN DIFERENTES SUSTRATOS AGRÍCOLAS
}

\section{PRODUCTIVE CAPACITY OF PLEUROTUS OSTREATUS USING DEHYDRATED ALFALFA AS SUPPLEMENT IN DIFFERENT AGRICULTURAL SUBSTRATES}

\author{
Omar Romero-Arenas ${ }^{1}$, Ma. Ángeles Valencia-De Ita ${ }^{2}$, J. António Rivera-Tapia ${ }^{3}$, Issac Tello-Salgado ${ }^{4}$ \\ Oscar A. Villarreal Espino-Barros ${ }^{5}$, M. Ángel Damián-Huato*1

\begin{abstract}
${ }^{1}$ Centro de Agroecología, Instituto de Ciencias; Benemérita Universidad Autónoma de Puebla (damianhuato@hotmail.com). ${ }^{2}$ Maestria en Ciencias Ambientales, Benemérita Universidad Autónoma de Puebla. ${ }^{3}$ Centro de Investigaciones en Ciencias Microbiológicas, ICUAP-BUAP. ${ }^{4}$ Instituto de Ciencias Biológicas; Universidad Autónoma de Morelos. ${ }^{5}$ Facultad de Medicina
\end{abstract} \\ Veterinaria y Zootecnia-BUAP.
}

\section{RESUMEN}

La investigación tuvo como objetivo suplementar con distintas proporciones de alfalfa (Medicago sativa $\mathrm{L}$ ) deshidratada los diferentes sustratos agrícolas más utilizados en la producción del hongo "seta" provenientes del Municipio de Tetela de Ocampo, Puebla-México. Se realizaron 17 tratamientos, incluyendo 5 testigos por cada sustrato empleado en un diseño experimental de bloques al azar, con un total de 85 unidades de producción. Los sustratos fueron inoculados y después de 28 días de incubación, éstos presentaron un $90 \%$ de colonización del micelio de la cepa CP-50 de Pleurotus ostreatus y al término de 121 días se finalizó el experimento obteniendo tres cosechas por cada tratamiento. La mejor combinación para la producción de setas fue el tratamiento "PT-3Al" con $17.94 \mathrm{~kg}$, el tratamiento que obtuvo la producción más baja fue "Al" con $3.51 \mathrm{~kg}$. La menor Eficiencia biológica (EB) es para el residuo paja de frijol con $46.84 \%$, además el sustrato más abundante de la región "rastrojo de maíz" incrementó su EB de 64.30 a $120.91 \%$ con un suplemento de $3 \mathrm{~kg}$ de alfalfa y una tasa de biodegradación de $64 \%$. La utilización de alfalfa deshidratada como suplemento en los sustratos convencionales, aumenta la producción de la cepa CP-50 en condiciones controladas.

Palabras claves: seta, producción, residuos agrícolas, eficiencia biológica y tasa de biodegradación.

* Autor responsable * Author for correspondence. Recibido: junio, 2014. Aprobado: agosto, 2017. Publicado como ARTÍCULO en ASyD 15: 145-160. 2018.

\section{Abstract}

The study had the objective of supplementing with different proportions of dehydrated alfalfa (Medicago sativa $\mathrm{L}$ ) the different agricultural substrates most frequently used in the production of the "oyster mushroom" fungus from the municipality of Tetela de Ocampo, Puebla, México. Seventeen treatments were performed, including 5 controls for each substrate used in a random experimental design in blocks, with a total of 85 production units. The substrates were inoculated and after 28 days of incubation, these presented $90 \%$ of mycelium colonization of the CP-50 strain of Pleurotus ostreatus and after 121 days the experiment was finished by obtaining three harvests for each treatment. The best combination for the production of oyster mushrooms was the "PT-3Al" treatment with $17.94 \mathrm{~kg}$, the treatment that obtained the lowest production was "Al" with $3.51 \mathrm{~kg}$. The lowest biological efficiency (BE) is for bean hay residue with $46.84 \%$, in addition to the most abundant substrate of the region, "maize stubble", increasing its BE from 64.30 to $120.91 \%$ with a supplement of $3 \mathrm{~kg}$ of alfalfa and a biodegradation rate of $64 \%$. The use of dehydrated alfalfa as supplement in the conventional substrates increases the production of the CP-50 strain under controlled conditions.

Key words: oyster mushroom, production, agricultural residues, biological efficiency and biodegradation rate.

\section{INTRODUCTION}

he global production of cultivated edible
mushrooms has increased more than 30 times
since 1978; by 2012, more than 31 million 


\section{INTRODUCCIÓN}

L a producción mundial de hongos comestibles cultivados ha aumentado más de 30 veces desde 1978; para 2012 se registraron más de 31 millones de toneladas, generando 20000 millones de dólares, con un consumo per cápita de hongos que supera los $4.70 \mathrm{~kg}$ anuales (Chang y Wasser, 2012; $\mathrm{FAO}, 2014)$.

China es el principal productor de hongos cultivados en el mundo, para el año 2013 produjo más de 30000 millones de kg de hongos frescos, representando $87 \%$ de la producción total, mientras que Estados Unidos y otros países produjeron alrededor de 3100 millones de kilos. Cabe destacar que en los Estados Unidos la producción ha aumentado alrededor de $11.7 \%$ en los últimos 10 años, generando 423.2 millones de kg en 2015 (Wu et al., 2013; Cunha y Pardo, 2017).

México es el mayor productor de Latinoamérica, generando alrededor de $80.8 \%$ de la producción total de la región, seguido por Brasil $(7.7 \%)$ y Colombia $(5.2 \%)$, ubicándose como el $13^{\circ}$ a nivel mundial (Romero-Arenas et al., 2015). Cabe resaltar que para el año 2011 se tuvo una producción de hongos frescos de 62374 toneladas, aumentando cada año (Martínez-Carrera et al., 2012). Además, la producción de setas (Pleurotus spp) en México se ha incrementado en los últimos 10 ańos; actualmente corresponde a una proporción de $4.76 \%$ de la producción total (Martínez-Carrera et al., 2016). Cabe destacar que el género Pleurotus es la segunda seta más cultivada; constituye aproximadamente $19 \%$ de la producción mundial, mientras que Auricularia contribuye con alrededor de $17 \%$. Los otros dos géneros, Agaricus y Flammulina, son responsables de 15 y $11 \%$ del volumen, respectivamente (Suárez y Nieto, 2013; Royse et al., 2016).

La producción de setas representa una alternativa accesible para incrementar la obtención de alimentos con alto valor proteico; $P$. ostreatus representa un alimento con 350 calorías comparado con la carne roja, que solo contiene 150 calorías o el pescado que contiene 101 (Romero-Arenas et al., 2010). En la actualidad la biotecnología aplicada al cultivo de hongos comestibles permite obtener grandes producciones en relativamente poco espacio, representando una agroindustria de gran importancia socioeconómica, tons were recorded, generating 20000 million dollars, with a per capita consumption of mushrooms that exceeds the $4.70 \mathrm{~kg}$ annually (Chang and Wasser, 2012; FAO, 2014).

China is the main producer of cultivated mushrooms in the world; by the year 2013 it produced more than 30000 million $\mathrm{kg}$ of fresh mushrooms, representing $87 \%$ of total production, while the United States and other countries produced around 3100 million kilos. It should be mentioned that in the United States production has increased around $11.7 \%$ in the last 10 years, generating 423.2 million $\mathrm{kg}$ in 2015 (Wu et al., 2013; Cunha and Pardo, 2017).

México is the largest producer in Latin America, generating around $80.8 \%$ of total production for the region, followed by Brazil (7.7 \%) and Colombia (5.2\%), rating as number 13 globally (RomeroArenas et al., 2015). It should be highlighted that by the year 2011, a production of 62374 tons of fresh mushrooms was obtained, increasing every year (Martínez-Carrera et al., 2012). In addition, the production of oyster mushrooms (Pleurotus spp) in México has increased in the last 10 years; currently, it corresponds to a proportion of $4.76 \%$ of total production (Martínez-Carrera et al., 2016). It should be mentioned that the Pleurotus genus is the second most cultivated mushroom; it constitutes approximately $19 \%$ of the world production, while Auricularia contributes around $17 \%$. The other genera, Agaricus and Flammulina, are responsible for 15 and $11 \%$ of the volume, respectively (Suárez and Nieto, 2013; Royse et al., 2016).

Oyster mushroom production represents an accessible alternative to increase food obtainment with high protein value; $P$. ostreatus represents a food with 350 calories compared to red meat, which only contains 150 calories or fish that contains 101 (Romero-Arenas et al., 2010). Currently, biotechnology applied to edible mushroom cultivation allows obtaining large productions in relatively small spaces, representing an agroindustry of great socioeconomic importance, due to the use of agroindustrial and agricultural residues, as well as an industry that generates employment (RomeroArenas et al., 2010; Fanadzo et al., 2010; Adebayo and Martinez-Carrera, 2015). This is why more than $40 \%$ of the municipalities of the state of Puebla produce edible mushrooms such as champignon $(A$. 
debido a la utilización de residuos agroindustriales y agrícolas, así como una industria generadora de empleos (Romero-Arenas et al., 2010; Fanadzo et al., 2010; Adebayo y Martinez-Carrera, 2015). Es por ello que más de $40 \%$ de los municipios del Estado de Puebla producen hongos comestibles como champiñón (A. bisporus), shiitake (L. edodes) y seta (P. ostreatus) [Medel et al., 2011].

La producción de setas presenta un potencial biotecnológico prometedor que abarca multitud de campos de aplicación (Andrino et al., 2011). Durante años el cultivo de setas se ha considerado importante para la economía familiar; además, existe el interés para mejorar la tecnología del cultivo, que ha ganado una atención considerable en los últimos años (Akinyele et al., 2012). Por tanto, se hace necesario utilizar nuevas tecnologías para aprovechar los subproductos agrícolas para el cultivo de $P$. ostreatus, conociendo que más de $70 \%$ de los residuos agrícolas son desechados al ambiente, generando daños a largo plazo y son desaprovechados en las zonas agrícolas. En este sentido, el aprovechar estos desechos como insumos para el cultivo de setas representa una actividad económica para generar un alimento rico en nutrientes a bajos costos de producción, obtenidos a partir de la fermentación de residuos agrícolas de la regiones rurales (López et al., 2008; Romero-Arenas et al., 2010).

El cultivo de alfalfa en México ha ocupado en los últimos 10 años un promedio de 376182.26 hectáreas anuales bajo condiciones de riego, mientras que la modalidad de temporal alcanzó 1404.76 hectáreas, lo que representa apenas $0.37 \%$ de la superficie total de este cultivo. Los principales estados productores son: Guanajuato, Chihuahua, Hidalgo, Baja California, Coahuila, San Luis Potosí, Sonora y Puebla, representando en conjunto $73 \%$ del total de la superficie nacional sembrada, con una producción en verde de 20359316.08 millones de toneladas y un valor de 5707422.75 millones de pesos para 2015 . Puebla es uno de los nueve principales productores de alfalfa en todo el país, con aproximadamente 18 717.50 mil hectáreas sembradas en las regiones de Tehuacán, Tecamachalco, Libres y Cholula, aportando $88.33 \%$, con un rendimiento de 5126.5 ton/ha (SAGARPA-SIAP, 2015).

La estrategia propuesta de la presente investigación representa el potencial para el cultivo de la CP50 de $P$. ostreatus, utilizando residuos de la región de bisporus), shiitake (L. edodes) and oyster mushroom (P. ostreatus) [Medel et al., 2011].

The production of oyster mushrooms presents a promising biotechnological potential that covers a multitude of application fields (Andrino et al., 2011). During years, oyster mushroom cultivation has been considered important for the family economy; in addition, there is an interest to improve the cultivation technology, which has gained considerable attention in recent years (Akinyele et al., 2012). Therefore, new technologies need to be used to take advantage of the agricultural byproducts for the cultivation of $P$. ostreatus, knowing that more than $70 \%$ of the agricultural residues are discarded into the environment, generating damages in the long term and being wasted in agricultural zones. In this sense, taking advantage of these wastes as inputs for the cultivation of oyster mushrooms represents an economic activity to generate a food rich in nutrients at low production costs, obtained from the fermentation of agricultural residues from rural regions (López et al., 2008; Romero-Arenas et al., 2010).

Alfalfa cultivation in México has used in the last 10 years an average of 376182.26 annual hectares under irrigation conditions, while the rainfed modality reached 1404.76 hectares, representing only $0.37 \%$ of the total surface of this crop. The main producing states are: Guanajuato, Chihuahua, Hidalgo, Baja California, Coahuila, San Luis Potosí, Sonora and Puebla, representing as a whole $73 \%$ of the total national surface sown, with a production in green of 20359316.08 million tons and a value of 5707422.75 million pesos for 2015. Puebla is one of the nine principal alfalfa producers in the whole country, with approximately 18717.50 thousand hectares sown in the regions of Tehuacán, Tecamachalco, Libres and Cholula, contributing $88.33 \%$, with a yield of 5126.5 ton/ ha (SAGARPA-SIAP, 2015).

The strategy proposed by this study represents the potential for the cultivation of the P. ostreatus CP50 strain, using residues from the region of Sierra Norte in the state of Puebla, such as: wheat, maize, barley and bean, complemented with different concentrations of dehydrated alfalfa, increasing the amount of raw protein and dry matter from the substrate (agricultural byproducts), thus increasing the biological efficiency of the crop, as well as the 
la Sierra Norte del Estado de Puebla, como: trigo, maíz, cebada y frijol, complementados con diferentes concentraciones de alfalfa deshidratada, aumentando la cantidad de proteína cruda y materia seca del sustrato (subproductos agrícolas), incrementando así, la eficiencia biológica del cultivo, así como el rendimiento para la producción de hongo seta en condiciones controladas.

\section{Materiales y Métodos}

El trabajo se realizó en la planta experimental de Investigación en producción de setas comestibles del Centro de Agroecología, perteneciente a la Benemérita Universidad Autónoma de Puebla (BUAP) en el Municipio de Tetela de Ocampo, que se localiza en la Sierra Norte del Estado de Puebla, México, cuyos límites geográficos son: $19^{\circ} 43^{\prime} 00^{\prime \prime}$ y $19^{\circ} 57^{\prime} 06^{\prime \prime} \mathrm{de}$ latitud norte y $97^{\circ} 38^{\prime} 42^{\prime \prime}$ y $97^{\circ} 54^{\prime} 06^{\prime \prime}$ de longitud Oeste. Sus colindancias son al Norte con Cuautempan y Tepetzintla, al Sur con Ixtacamaxtitlán, al Oeste con Xochiapulco y Zautla, y al Oriente con Aquixtla, Zacatlán e Ixtacamaxtitlán (Enciclopedia de los municipios de Puebla, 2015).

La cepa CP-50 de P. ostreatus (Jacq. ex Fr.) Kumm., empleada en el estudio, proviene del Centro de Recursos Genéticos de Hongos Comestibles (CREGENHC) del Colegio de Postgraduados y está depositada en el Cepario de Hongos Comestibles del Campus Puebla. La cepa es mantenida en un medio compuesto de agar de dextrosa y papa (PDA) marca Bioxon, a $28^{\circ} \mathrm{C}$ (Sobal et al., 2007).

Para la inoculación de la cepa CP-50 se utilizaron diversos esquilmos agrícolas, los cuales fueron: paja de trigo (Triticum aestivum L.), paja de cebada (Hordeum vulgare L.), pajilla de frijol (Phaseolus vulgaris L.), rastrojo de maíz (Zea mays L.) y alfalfa (Medicago sativa L.), que se adquirieron en la región de Tetela de Ocampo, Puebla, México. En el laboratorio, los materiales se fragmentaron mecánicamente en porciones de 1 a $3 \mathrm{~cm}$ de longitud; en el caso de la alfalfa se deshidrató en un horno de secado $\left(50{ }^{\circ} \mathrm{C}\right)$ hasta alcanzar peso constante y pérdida de agua por encima del $3 \%$ (Buswell et al., 1993).

Los sustratos fueron pasteurizados en agua caliente a $80{ }^{\circ} \mathrm{C} / 1 \mathrm{~h}$.; transcurrido el tiempo de pasteurización se transportaron al área de siembra para permitir su enfriamiento y el escurrimiento del exceso de humedad (aproximadamente de 30 minutos) [RomeroArenas et al., 2010]. Posteriormente se procedió a la yield for the production of the oyster mushroom under controlled conditions.

\section{Materials and Methods}

The study was performed in the experimental plant for research in edible oyster mushroom production in the Agroecology Center, belonging to the Benemérita Universidad Autónoma de Puebla (BUAP) in the municipality of Tetela de Ocampo, located on the Sierra Norte in the state of Puebla, México, whose geographic limits are: $19^{\circ} 43^{\prime} 00^{\prime \prime}$ and $19^{\circ} 57^{\prime} 06^{\prime \prime}$ of latitude North and $97^{\circ} 38^{\prime} 42^{\prime \prime}$ and $97^{\circ} 54^{\prime} 06^{\prime \prime}$ of longitude West. It borders north with Cuautempan and Tepetzintla, south with Ixtacamaxtitlán, west with Xochiapulco and Zautla, and east with Aquixtla, Zacatlán and Ixtacamaxtitlán (Enciclopedia de los municipios de Puebla, 2015).

The CP-50 strain of $P$. ostreatus (Jacq. ex Fr.) Kumm., used in the study, comes from the Genetic Resources Center of Edible Mushrooms (Centro de Recursos Genéticos de Hongos Comestibles, CREGENHC) of Colegio de Postgraduados and is deposited in the Edible Mushroom Strain Collection of the Puebla Campus. The strain is maintained in a medium made up of potato dextrose agar (PDA) Bioxon brand, at $28{ }^{\circ} \mathrm{C}$ (Sobal et al., 2007).

For the inoculation of the CP-50 strain, various agricultural residues were used, which were the following: wheat hay (Triticum aestivum L.), barley hay (Hordeum vulgare L.), bean straw (Phaseolus vulgaris L.), maize stubble (Zea mays L.) and alfalfa (Medicago sativa L.), which were obtained in the region of Tetela de Ocampo, Puebla, México. In the laboratory, the materials were fragmented mechanically into portions of 1 to $3 \mathrm{~cm}$ of length; in the case of alfalfa, it was dehydrated in a drying stove $\left(50{ }^{\circ} \mathrm{C}\right)$ until reaching constant weight and water loss above 3\% (Buswell et al., 1993).

The substrates were pasteurized in hot water at 80 ${ }^{\circ} \mathrm{C} / 1$ h.; after this time of pasteurization, they were transported to the sowing area to allow their cooling and dripping of excess moisture (approximately 30 minutes) [Romero-Arenas et al., 2010]. Later, sowing was performed (inoculation) and transparent plastic bags of $40 \times 60 \mathrm{~cm}$ were prepared, with a capacity of $6 \mathrm{~kg}$ (humid weight) of each substrate used. The experiment was designed in random blocks, which 
siembra (inoculación) y se prepararon bolsas de plástico trasparente de $40 \times 60 \mathrm{~cm}$, con capacidad de $6 \mathrm{~kg}$ (peso húmedo) de cada sustrato empleado. El experimento se diseñó en bloques al azar, el cual contó con 17 tratamientos con cinco repeticiones por cada uno y cinco grupos de control (Cuadro 1).

Las bolsas se sembraron homogéneamente con la "semilla" previamente preparada en una relación 1:10. Las muestras sembradas se incubaron a temperatura ambiente $\left(26 \pm 2{ }^{\circ} \mathrm{C}\right)$; cuando el micelio del hongo colonizó completamente los sustratos y mostró la aparición de primordios, las bolsas se trasladaron al cuarto de fructificación donde se propiciaron condiciones controladas con respecto a la humedad (70 a $80 \%)$, temperatura (18 a $\left.25^{\circ} \mathrm{C}\right)$, luz diurna indirecta y extracción de aire por 1 h, cada 8 h (Garzón et al., 2008).

Los datos de producción que se registraron fueron: peso fresco de hongos colectados por cosecha, eficiencia biológica $[\mathrm{EB}=$ Peso fresco de los hongos cosechados (g)/Peso seco del substrato (g) $] \times 100$ (Tchierpe y Hartman, 1977; Salmones et al., 1997), tasa de producción $(\mathrm{TP}=\mathrm{EB} /$ tiempo transcurrido desde la inoculación hasta la última cosecha) (Reyes et al., 2004) y tasa de biodegradación $(\mathrm{TB}=$ Peso seco del sustrato inicial-Peso seco del sustrato final / Peso seco del sustrato inicial $\times 100$ ). Además, la productividad se expresó en términos de gramos de hongos had 17 treatments with five repetitions for each one and five control groups (Table 1).

The bags were sown homogenously with the "seed" previously prepared in a 1:10 rate. The samples sown were incubated at room temperature $\left(26 \pm 2{ }^{\circ} \mathrm{C}\right)$; when the mycelium of the mushroom colonized the substrates completely and showed the appearance of primordia, the bags were transported to the fructification room where controlled conditions were promoted with regards to moisture (70 to $80 \%$ ), temperature (18 to $25^{\circ} \mathrm{C}$ ), indirect day light, and air extraction for 1 h, every 8 h (Garzón et al., 2008).

The production data that were recorded were: fresh weight of mushrooms collected per harvest, biological efficiency $[\mathrm{BE}=$ Fresh weight of the mushroom harvested (g)/Dry weight of the substrate (g) $\times 100$ (Tchierpe and Hartman, 1977; Salmones et al., 1997), production rate $(\mathrm{PR}=\mathrm{BE} /$ time that passed since inoculation until the last harvest) (Reyes et al., 2004) and biodegradation rate $(\mathrm{BR}=$ Dry weight of the initial substrate - Dry weight of the final substrate / Dry weight of the initial substrate $\times 100$ ). In addition, the productivity was expressed in terms of grams of fresh mushrooms per production cycle (Romero-Arenas et al., 2010).

The SPSS Statistics package, version 17 (Statistical Package for the Social Sciences), was used. The data

Cuadro 1. Tratamientos evaluados, así como su respectiva descripción y código para su identificación.

Table 1. Treatments evaluated, as well as their corresponding description and code for their identification.

\begin{tabular}{ll}
\hline Código & \multicolumn{1}{c}{ Descripción de los tratamientos } \\
\hline PT & \\
PC & Grupo Testigo $(6 \mathrm{~kg})$ sustrato \\
RF & \\
Al & \\
PT-2 Al & Paja de trigo $(4 \mathrm{~kg})+2 \mathrm{~kg}$ de alfalfa deshidratada \\
PC-2 Al & Paja de cebada $(4 \mathrm{~kg})+2 \mathrm{~kg}$ de alfalfa deshidratada \\
PF-2 Al & Pajilla de frijol $(4 \mathrm{~kg})+2 \mathrm{~kg}$ de alfalfa deshidratada \\
RM-2 Al & Rastrojo de maíz $(4 \mathrm{~kg})+2 \mathrm{~kg}$ de alfalfa deshidratada \\
PT-2.5 Al & Paja de trigo $(3.5 \mathrm{~kg})+2.5 \mathrm{~kg}$ de alfalfa deshidratada \\
PC-2.5 Al & Paja de cebada $(3.5 \mathrm{~kg})+2.5 \mathrm{~kg}$ de alfalfa deshidratada \\
PF-2.5 Al & Pajilla de frijol $(3.5 \mathrm{~kg})+2.5 \mathrm{~kg}$ de alfalfa deshidratada \\
RM-2.5 Al & Rastrojo de maíz $(3.5 \mathrm{~kg})+2.5 \mathrm{~kg}$ de alfalfa deshidratada \\
PT-3 Al & Paja de trigo $(3 \mathrm{~kg})+3 \mathrm{~kg}$ de alfalfa deshidratada \\
PC-3 Al & Paja de cebada $(3 \mathrm{~kg})+3 \mathrm{~kg}$ de alfalfa deshidratada \\
PF-3 Al & Pajilla de frijol $(3 \mathrm{~kg})+3 \mathrm{~kg}$ de alfalfa deshidratada \\
RM-3 Al & Rastrojo de maíz $(3 \mathrm{~kg})+3 \mathrm{~kg}$ de alfalfa deshidratada \\
\hline
\end{tabular}

PT: Trigo, PC: Cebada, RM: Maíz PF: Frijol, Al: Alfalfa. \& PT: Wheat, PC: Barley, RM: Maize PF: Bean, Al: Alfalfa. 
frescos por ciclo de producción (Romero-Arenas et al., 2010).

Se utilizó el paquete estadístico SPSS Statistics, versión 17 (Statistical Package for the Social Sciences). Los datos obtenidos se procesaron con el análisis de varianza (ANOVA) y posteriormente se aplicó la prueba de comparaciones múltiples de Tukey $(\mathrm{p} \leq 0.05)$ para determinar las diferencias entre tratamientos.

Para la determinación de materia seca, proteína cruda, cenizas, extracto etéreo, fibra neutro detergente (FND) y fibra ácido detergente (FAD) se siguieron los métodos oficiales de análisis químico proximal (A.O.A.C., 1980; Franco, 1990). Los sustratos se molieron con la ayuda de un molino utilizando malla No. 20; posteriormente se utilizó 1 y 2 g, dependiendo del sustrato y del análisis a realizar.

\section{Resultados y Discusión}

\section{Producción total de la CP-50}

La producción de la cepa CP-50 de P. ostreatus en los tratamientos evaluados se efectuó de acuerdo con la metodología descrita anteriormente y duró 121 días, desde la siembra del micelio en cajas Petri hasta la obtención de la tercera cosecha. Cedano et al. (1993) reportaron que $P$. ostreatoroseus inició la fructificación después de 31 días de incubación y 60 días producción; resultados similares a esta investigación, donde la cepa CP-50 presentó su primer fructificación entre los 38 días en la mayoría de los tratamientos hasta los 73 días de producción. En cuanto al período de cosecha, Mora (2004) reportó un período de cosecha de cinco semanas, utilizando la cepa (HEMIM-50) de P. ostreatus sobre paja de trigo; Gómez (2004) menciona un período medio de seis semanas, con la misma cepa y en el mismo sustrato. El período de cosecha para la cepa CP-50 en este trabajo fue entre seis y siete semanas, coincidiendo con lo reportado por Gómez (2004).

El ciclo de cultivo de la CP-50 de P. ostreatus osciló entre 100 días y 121 días, con media de 38 días de colonización, más 45 días de fructificación. En su trabajo, Aguirre (2000) reportó un ciclo de cultivo de 119 días (32 días de colonización, más 84 días de fructificación); Gómez (2004) reportó un ciclo de cultivo de 88 días para la cepa (HEMIM-50) de P. ostreatus, 53 días de colonización, más 35 días de obtained were processed with the analysis of variance (ANOVA) and later Tukey's multiple comparison test $(\mathrm{p} \leq 0.05)$ was used to determine the differences between treatments.

To determine dry matter, raw protein, ash, ethereal extract, neutral detergent fiber (NDF) and acid detergent fiber (ADF), the official proximal chemical analysis methods were followed (A.O.A.C., 1980; Franco, 1990). The substrates were ground with the help of a mill using mesh No. 20; later, 1 and $2 \mathrm{~g}$ were used, depending on the substrate and the analysis to be performed.

\section{Results AND Discussion}

\section{Total production of CP-50}

The production of the P. ostreatus CP-50 strain in the treatments evaluated was done according to the methodology described previously and lasted 121 days, since sowing of the mycelium in Petri dishes until obtaining the third harvest. Cedano et al. (1993) reported that $P$. ostreatoroseus began fructification after 31 days of incubation and 60 days of production; similar results to this research, where the CP-50 strain presented its first fructification between 38 days in most of the treatments and up until 73 days of production. Regarding the harvest period, Mora (2004) reported a harvest period of five weeks, using the strain (HEMIM-50) of P. ostreatus on wheat hay; Gómez (2004) mentions an average period of six weeks, with the same strain and in the same substrate. The harvesting period for the CP-50 strain in this study was between six and seven weeks, which agrees with what was reported by Gómez (2004).

The cultivation cycle of the $P$. ostreatus CP50 strain ranged between 100 days and 121 days, with a mean of 38 days of colonization, plus 45 days of fructification. In his study, Aguirre (2000) reported a cultivation cycle of 119 days (32 days of colonization, plus 84 days of fructification); Gómez (2004) reported a cultivation cycle of 88 days for the strain (HEMIM-50) of P. ostreatus, 53 days of colonization, plus 35 days of fructification. Vernero et al. (2010) reported a cultivation cycle of 104 days for $P$. ostreatus in wheat hay substrate, similar results to those obtained in this research study (Table 2).

To quantify the fresh weight of the sporocarps produced, three harvests were carried out in a lapse 
fructificación. Vernero et al. (2010) reportaron un ciclo de cultivo de 104 días para $P$. ostreatus en sustrato paja de trigo, resultados similares a los obtenidos en este trabajo de investigación (Cuadro 2).

Para cuantificar el peso fresco de los esporomas producidos se realizaron tres cosechas en un lapso de 45 días. El mayor rendimiento en peso fresco se obtuvo en la primera cosecha y disminuyó en las siguientes. En promedio, la primera cosecha obtuvo entre 46 y $60 \%$; en el segundo corte se obtuvo de 15 a $36 \%$; por último, 8 a $26 \%$ de la producción total obtenida.

La producción total en los tratamientos testigos se observa en la Figura 1, donde el sustrato de paja de trigo PT alcanzó la mayor producción, con un total de $12.87 \mathrm{~kg}$, contando las tres cosechas realizadas. Cabe mencionar que la paja de trigo es el sustrato tradicional, en el cual se lleva a cabo esta actividad productiva (Kumari y Achal, 2008). La paja de cebada fue el que ocupó el segundo lugar, con $10.22 \mathrm{~kg}$, seguido por rastrojo de maíz, con $6.43 \mathrm{~kg}$; la pajilla de frijol obtuvo $4.68 \mathrm{~kg}$ y, por último, alfalfa deshidratada, reportándose diferencias altamente significativas con la prueba de rango múltiple de Tukey $(\mathrm{p} \leq 0.05)$.

La producción total obtenida de la cepa CP-50 de $P$. ostreatus en paja de cebada suplementada con alfalfa deshidratada en diferentes concentraciones hace una comparación entre los tratamientos y el testigo tradicional (paja de trigo). En este caso, la mayor producción en peso fresco se obtuvo con el tratamiento PC-3Al que corresponde a paja de cebada suplementada con $3 \mathrm{~kg}$ de alfalfa deshidratada, dándonos un total de $13.32 \mathrm{~kg}$ (Figura 2); la segunda mejor producción la presentó el tratamiento PC-2.5Al cebada suplementada con $2.5 \mathrm{~kg}$ de alfalfa deshidratada, con $13.11 \mathrm{~kg}$. El tratamiento que presentó la menor producción fue cebada sin suplementación (PC), con una producción total de $10.22 \mathrm{~kg}$, reportando diferencias significativas con la prueba de rango múltiple de Tukey $(\mathrm{p} \leq 0.05)$.

La producción total obtenida en el tratamiento maíz suplementado con alfalfa deshidratada en diferentes concentraciones reportó diferencias altamente significativas con la prueba de rango múltiple de Tukey $(\mathrm{p} \leq 0.05)$. La mayor producción en peso fresco se obtuvo con el tratamiento RM-3Al, que corresponde a rastrojo de maíz suplementado con $3 \mathrm{~kg}$ de alfalfa deshidratada, obteniendo una producción
Cuadro 2. Duración por etapas del ciclo de cultivo de la cepa CP-50 de P. ostreatus.

Table 2. Duration by stages of the cultivation cycle of the $P$. ostreatus CP-50 strain.

\begin{tabular}{lc}
\hline \multicolumn{1}{c}{ Etapa } & Duración en días \\
\hline Crecimiento del micelio en cajas Petri & 10 \\
Crecimiento del micelio en los Masters & 18 \\
Obtención de la semilla & 20 \\
Colonización de la semilla en los & 28 \\
diferentes tratamientos & 10 \\
Fructificación de la primera cosecha & 15 \\
Fructificación de la segunda cosecha & 20 \\
Fructificación de la tercera cosecha & 121 \\
\hline Total & \\
\hline
\end{tabular}

of 45 days. The highest yield in fresh weight was obtained in the first harvest and decreased in the next ones. In average, the first harvest obtained between 46 and $60 \%$; in the second cut, it was 15 to $36 \%$; lastly, 8 to $26 \%$ of the total production obtained.

The total production in the control treatments is shown in Figure 1, where the wheat hay substrate TP reached the highest production, with a total of $12.87 \mathrm{~kg}$, counting the three harvests carried out. It should be mentioned that wheat hay is the traditional substrate, on which this productive activity is carried out (Kumari and Achal, 2008). Barley hay was the

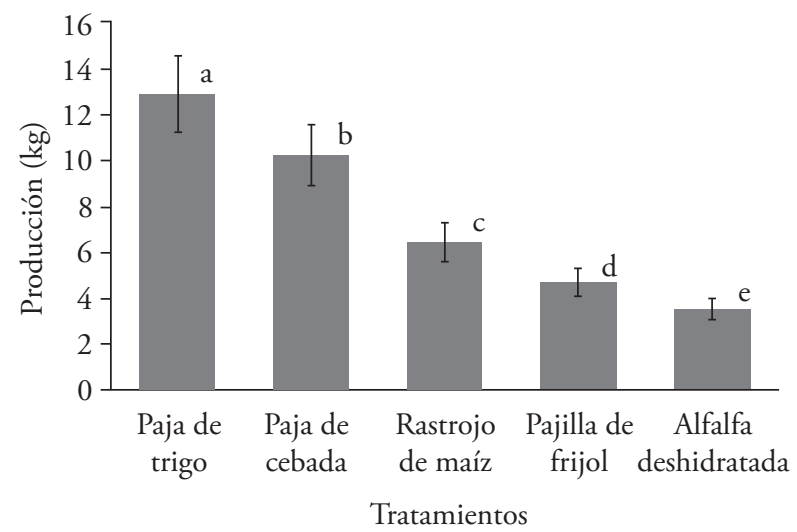

Letras diferentes indican diferencias significativas con la prueba de rango múltiple de Tukey $(\mathrm{p} \leq 0.05)$. Different letters indicate significant differences with the multiple range Tukey test $(\mathrm{p} \leq 0.05)$.

Figura 1. Producción total de la cepa CP-50 de P. ostreatus en tratamientos testigos sin alfalfa deshidratada.

Figure 1. Total production of the CP-50 strain of $P$. ostreatus in control treatments without dehydrated alfalfa. 


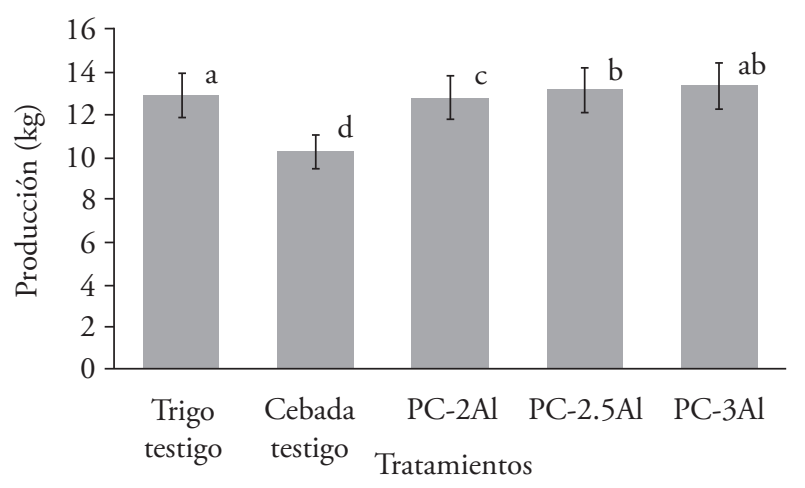

*Letras diferentes indican diferencias significativas con la prueba de rango múltiple de Tukey $(\mathrm{p} \leq 0.05)$. Different letters indicate significant differences with the multiple range Tukey test $(\mathrm{p} \leq 0.05)$.

Figura 2. Producción total de la cepa CP-50 de P. ostreatus en sustrato paja de cebada suplementada con alfalfa deshidratada.

Figure 2. Total production of the CP-50 strain of P. ostreatus in barley haw substrate supplemented with dehydrated alfalfa.

total de $12.09 \mathrm{~kg}$ (Figura 3). La segunda mejor producción se presentó con el tratamiento testigo "Paja de trigo", con $12.87 \mathrm{~kg}$. El tratamiento que presentó una menor producción fue rastrojo de maíz "RM", con $6.43 \mathrm{~kg}$. Cabe mencionar que los tratamientos suplementados con alfalfa deshidratada superaron al rastrojo de maíz; además, mostró una similitud con la paja de trigo. Un estudio realizado por Flores (2012) menciona que la combinación de bagazo de yuca y paja de trigo tuvo un mayor rendimiento en comparación con el bagazo de yuca solo. De manera similar, Rajak et al. (2011) reportaron que con la combinación de paja de arroz (sustrato) y hierbas silvestres de la India (co-sustrato) obtuvieron el mayor rendimiento en comparación con las hierbas silvestres solas. Esto podría ser explicado por el hecho de que en la mezcla los sustratos típicos aportan los nutrientes necesarios para la incubación y desarrollo de primordios y formación de esporóforos durante la colonización; mientras que los co-sustratos, cuya descomposición es más lenta que la de los sustratos, proveen los requerimientos nutricionales necesarios para los estadios posteriores de crecimiento.

La producción total obtenida en el tratamiento pajilla de frijol suplementada con alfalfa deshidratada presentó la mayor producción en peso fresco con el tratamiento (PT) que corresponde a paja de trigo one in second place with $10.22 \mathrm{~kg}$, followed by maize stubble, with $6.43 \mathrm{~kg}$; bean straw obtained 4.68 $\mathrm{kg}$, and, lastly, dehydrated alfalfa, showing highly significant differences with the multiple range Tukey test $(\mathrm{p} \leq 0.05)$.

The total production obtained from the $P$. ostreatus CP-50 strain in barley hay supplemented with dehydrated alfalfa in different concentrations makes a comparison between the treatments and the traditional control (wheat hay). In this case, the highest production in fresh weight was obtained with the PC-3Al treatment that corresponds to barley hay supplemented with $3 \mathrm{~kg}$ of dehydrated alfalfa, giving us a total of $13.32 \mathrm{~kg}$ (Figure 2); the second best production presented the treatment PC-2.5Al barley supplemented with $2.5 \mathrm{~kg}$ of dehydrated alfalfa, with $13.11 \mathrm{~kg}$. The treatment that presented the lowest production was barley without supplementation (PC), with a total production of $10.22 \mathrm{~kg}$, reporting significant differences with the multiple range Tukey test $(\mathrm{p} \leq 0.05)$.

The total production obtained in the maize treatment supplemented with dehydrated alfalfa in different concentrations reported highly significant differences with the multiple range Tukey test

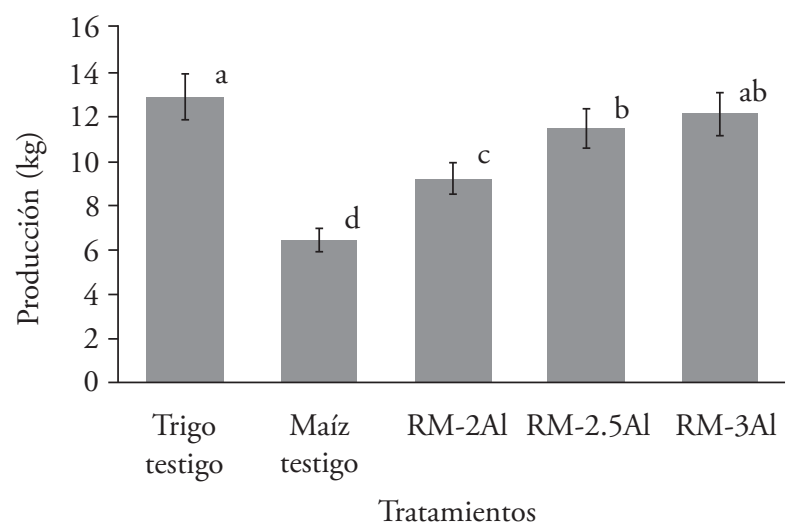

* Letras diferentes, indican diferencias significativas con la prueba de rango múltiple de Tukey $(\mathrm{p} \leq 0.05)$. Different letters indicate significant differences with the multiple range Tukey test $(\mathrm{p} \leq 0.05)$.

Figura 3. Producción total de la cepa CP-50 de P. ostreatus en sustrato rastrojo de maíz suplementado con alfalfa deshidratada.

Figure 3. Total production of the CP-50 strain of $P$. ostreatus in maize stubble supplemented with dehydrated alfalfa. 
sin suplementación, dándonos un total de $12.87 \mathrm{~kg}$ (Figura 4); la segunda mejor producción la presentó el tratamiento PF-3Al, pajilla de frijol suplementada con tres kilogramos de alfalfa deshidratada con $8.41 \mathrm{~kg}$. El tratamiento que presentó menor producción fue el testigo pajilla de frijol (PF), con $4.68 \mathrm{~kg}$, reportándose diferencias significativas $(\mathrm{p} \leq 0.05)$.

\section{Cuantificación de la EB, TP y TB de la CP-50}

La eficiencia biológica EB no solo depende del balance nutricional conseguido, sino también de otros aspectos ambientales, como la capacidad de retención de agua del sustrato, la aireación y la humedad relativa en varias etapas del cultivo (Mane et al., 2007). Mora y Martínez-Carrera (2007) reportaron eficiencias biológicas de $39 \%$ a $162 \%$ en paja de trigo, con cepas comerciales de Pleurotus spp., resultados similares a la presente investigación. El tratamiento PT-3Al presentó una EB de $179.40 \%$, parecidos a los encontrados por Salmones et al. (1997) donde reportaron EB de 75.6 al $68 \%$ en 19 cepas de Pleurotus spp., en un sustrato de paja de cebada, valores inferiores a los de esta investigación (133.23 \%). López et al. (2005) citan que el sustrato de rastrojo de maíz presenta una

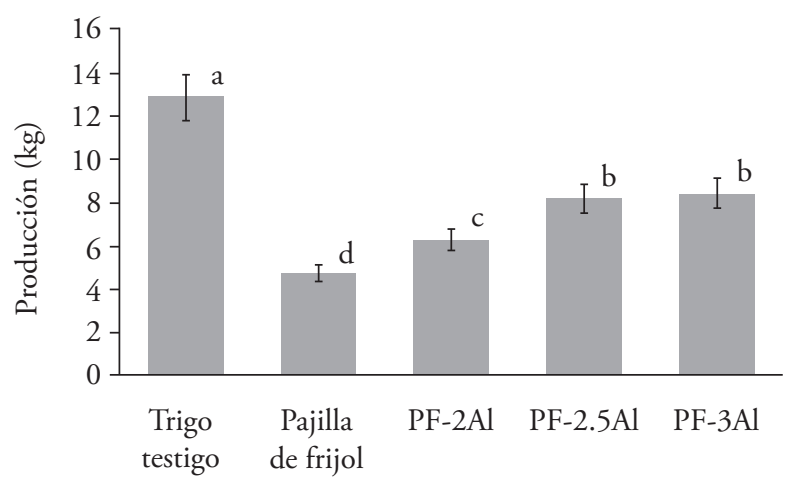

Tratamientos

*Letras diferentes, indican diferencias significativas con la prueba de rango múltiple de Tukey $(\mathrm{p} \leq 0.05)$. Different letters indicate significant differences with the multiple range Tukey test $(\mathrm{p} \leq 0.05)$

Figura 4. Producción total de la cepa CP-50 de P. ostreatus en sustrato pajilla de frijol suplementada con alfalfa deshidratada.

Figure 4. Total production of the CP-50 strain of $P$. ostreatus in bean straw substrate supplemented with dehydrated alfalfa. $(p \leq 0.05)$. The highest production in fresh weight was obtained with the RM-3Al treatment, which corresponds to maize stubble supplemented with $3 \mathrm{~kg}$ of dehydrated alfalfa, obtaining a total production of $12.09 \mathrm{~kg}$ (Figure 3). The second best production was found with the "Wheat hay" control treatment, with $12.87 \mathrm{~kg}$. The treatment that presented a lower production was maize stubble "RM", with $6.43 \mathrm{~kg}$. It should be mentioned that the treatments supplemented with dehydrated alfalfa outperformed maize stubble; in addition, it showed a similarity with wheat hay. A study performed by Flores (2012) mentions that the combination of yucca husk and wheat hay had a higher yield in comparison to the yucca husk alone. Similarly, Rajak et al. (2011) reported that with the combination of rice hay (substrate) and wild weeds from India (co-substrate), they obtained the highest yield in comparison to the wild weeds alone. This could be explained by the fact that the mixture of typical substrates contributes the nutrients necessary for the incubation and development of primordia and the formation of sporophores during colonization, while the co-substrates, whose decomposition is slower than that of substrates, provide the nutritional requirements necessary for the later phases of growth.

The total production obtained in the bean straw treatment supplemented with dehydrated alfalfa presented the highest production in fresh weight with the treatment (PT) that corresponds to wheat hay without supplementation, giving us a total of $12.87 \mathrm{~kg}$ (Figure 4); the second best production was presented by treatment PF-3Al, bean straw supplemented with three kilograms of dehydrated alfalfa with $8.41 \mathrm{~kg}$. The treatment that presented the lowest production was the control bean straw $(\mathrm{PF})$, with $4.68 \mathrm{~kg}$, reporting significant differences $(\mathrm{p} \leq 0.05)$.

\section{Quantification of BE, PR and BR for CP-50}

The biological efficiency (BE) not only depends on the nutritional balance attained, but also on other environmental aspects, such as the capacity for water retention of the substrate, aeriation and relative moisture in several stages of cultivation (Mane et al., 2007). Mora and Martínez-Carrera (2007) reported biological efficiencies of $39 \%$ to $162 \%$ in wheat hay, with commercial strains of Pleurotus spp., results 
Cuadro 3. Eficiencia Biológica (EB).

Table 3. Biological Efficiency (BE).

\begin{tabular}{lcccc}
\hline & & \multicolumn{2}{c}{ EB \% } \\
Tratamientos & EB \% & \multicolumn{2}{c}{ Suplementación de alfalfa deshidratada } \\
\cline { 3 - 5 } & Testigos & 2.0 & $157.27 \mathrm{a}$ & $179.40 \mathrm{a}$ \\
\hline Paja de trigo & $128.70 \mathrm{a}$ & $154.08 \mathrm{a}$ & $131.11 \mathrm{~b}$ & $133.23 \mathrm{~b}$ \\
Paja de cebada & $102.20 \mathrm{~b}$ & $127.66 \mathrm{~b}$ & $114.50 \mathrm{c}$ & $120.91 \mathrm{c}$ \\
Rastrojo de maíz & $64.30 \mathrm{c}$ & $91.85 \mathrm{c}$ & $81.63 \mathrm{~d}$ & $84.11 \mathrm{~d}$ \\
Pajilla de frijol & $46.84 \mathrm{~d}$ & $62.70 \mathrm{~d}$ & & \\
Alfalfa deshidratada & $35.13 \mathrm{e}$ & & & \\
\hline
\end{tabular}

EB \%: porcentaje de eficiencia biológica. *Medias con letras diferentes indican diferencias significativas con la prueba de Tukey (P $\leq 0.05)$. * EB \%: percentage of biological efficiency. ${ }^{*}$ Means with different letters indicate significant differences with the Tukey test $(\mathrm{P} \leq 0.05)$.

EB de $97 \%$, superiores a las del grupo control RM y RM-2Al en esta investigación (64.30 y $91.85 \%$, respectivamente), pero inferiores al ser suplementado con alfalfa deshidratada al 2.5 y $3.0 \mathrm{~kg}$, obteniendo EB de 114.50 y $120.91 \%$ (Cuadro 3). La EB para el residuo pajilla de frijol sin suplementar con alfalfa deshidratada es de $46.84 \%$; al complementar este residuo agrícola con alfalfa deshidratada se puede observar un incremento de $60 \%$ de su EB, superiores al rastrojo de maíz (RM), pero inferiores a la paja de trigo PT.

La tasa de producción (TP) más alta se obtuvo en la paja de trigo suplementada con $3.0 \mathrm{~kg}$ de alfalfa deshidratada (1.48\%); la menor TP, en el tratamiento alfalfa deshidratada (0.29\%). Mora (2004) reportó una TP de $1.57 \%$ en paja de trigo; Gaitán-Hernández et al. (2009) registraron una TP de $0.76 \%$ en paja de cebada, resultados similares a los obtenidos en la presente investigación (Cuadro 4).

Asimismo, la tasa de biodegradación TB que presentó la CP-50 de P. ostreatus mostró que es capaz de similar to this study. The PT-3Al treatment presented a BE of $179.40 \%$, similar to that found by Salmones et al. (1997) where they reported a BE of 75.6 to $68 \%$ in 19 strains of Pleurotus spp., in a substrate of barley hay, lower values than those from this study (133.23 \%). López et al. (2005) cite that maize stubble substrate presents a BE of $97 \%$, higher than those from the control group RM and $\mathrm{RM}-2 \mathrm{Al}$ in this research (64.30 and $91.85 \%$, respectively), although lower when being supplemented with dehydrated alfalfa at 2.5 and $3.0 \mathrm{~kg}$, obtaining BE of 114.50 and $120.91 \%$ (Table 3). The BE for bean straw residue without supplementing with dehydrated alfalfa is $46.84 \%$; when complementing this agricultural residue with dehydrated alfalfa, an increase of $60 \%$ of its BE can be observed, higher than maize stubble (RM), but lower than the wheat hay (PT).

The highest production rate (PR) was obtained in wheat hay supplemented with $3.0 \mathrm{~kg}$ of dehydrated alfalfa $(1.48 \%)$; the lowest PR, in the dehydrated

Cuadro 4. Tasa de producción (TP).

Table 4. Production rate (PR).

\begin{tabular}{lcccc}
\hline & & & \multicolumn{2}{c}{ TP (\%) } \\
\multicolumn{1}{c}{ Tratamientos } & TP \% & & Suplementación de alfalfa deshidratada \\
\cline { 3 - 5 } & Testigos & 2.0 & 2.5 & 3.0 \\
\hline Paja de Trigo & $1.06 \mathrm{a}$ & $1.27 \mathrm{a}$ & $1.30 \mathrm{a}$ & $1.48 \mathrm{a}$ \\
Paja de Cebada & $0.84 \mathrm{a}$ & $1.06 \mathrm{~b}$ & $0.95 \mathrm{~b}$ & $1.10 \mathrm{~b}$ \\
Rastrojo de Maíz & $0.53 \mathrm{~b}$ & $0.76 \mathrm{c}$ & $0.67 \mathrm{c}$ & $0.70 \mathrm{c}$ \\
Pajilla de Frijol & $0.39 \mathrm{c}$ & $0.52 \mathrm{~d}$ & & $\mathrm{c}$ \\
Alfalfa Deshidratada & $0.29 \mathrm{c}$ & & & \\
\hline
\end{tabular}

TP \%: porcentaje de Tasa de producción. ${ }^{*}$ Medias con letras diferentes indican diferencias significativas con la prueba de Tukey (P $\left.\leq 0.05\right)$. * TP \%: percentage of production rate. ${ }^{*}$ Means with different letters indicate significant differences with the Tukey test (P $\left.\leq 0.05\right)$. 
convertir hasta $70 \%$ del substrato en alimento para consumo humano, sobre todo en el de paja de trigo suplementado a $3.0 \mathrm{~kg}$ de alfalfa deshidratada, que fue la TB más alta en comparación con el sustrato alfalfa deshidratada, con $32 \%$ y pajilla de frijol con $46 \%$ (Cuadro 5).

La temperatura media dentro del área de incubación de las unidades de producción fue de $22.1^{\circ} \mathrm{C}$ (mínima) y de $28.16{ }^{\circ} \mathrm{C}$ (máxima) durante los meses de febrero a mayo, que fue el período en el que las unidades de producción permanecieron dentro del área de incubación. Mora (2004) reportó una temperatura media semanal de $20.3{ }^{\circ} \mathrm{C}$ a $27.7^{\circ} \mathrm{C}$, con una máxima de 27.2 y una mínima de $20.0^{\circ} \mathrm{C}$, y Gómez (2004) reportó valores que van de $\operatorname{los} 23^{\circ} \mathrm{C}$ a $26.7^{\circ} \mathrm{C}$ para los meses de abril a mayo, similares a los reportados en esta investigación. En cuanto al área de fructificación, la temperatura media osciló entre $18.4^{\circ} \mathrm{C}$ (mínima) y $25.5^{\circ} \mathrm{C}$ (máxima) durante los meses de junio a septiembre, donde se obtuvieron las últimas cosechas. Gómez (2004) reportó una temperatura media entre 21 y $23.9^{\circ} \mathrm{C}$ para las semanas de junio a julio; además, una humedad relativa que osciló entre 76.5 a $87.3 \%$ para los meses de mayo a junio, resultados similares a los de la presente investigación, donde la humedad relativa promedio en el módulo rústico de producción dentro del área de fructificación fue de $78.3 \%$. Cabe destacar que las temperaturas de incubación y fructificación que se presentaron en el módulo de producción tuvieron valores más altos que los reportados por Mora (2004) y Gómez (2004), debido a las condiciones ambientales de ubicación. alfalfa treatment (0.29\%). Mora (2004) reported a PR of $1.57 \%$ in wheat hay; Gaitán-Hernández et al. (2009) reported a PR of $0.76 \%$ in barley hay, similar results to those obtained in this study (Table 4).

Likewise, the biodegradation rate (BR) presented by the P. ostreatus CP-50 strain showed that it is capable of converting up to $70 \%$ of the substrate in food for human consumption, particularly in that of wheat hay supplemented at $3.0 \mathrm{~kg}$ of dehydrated alfalfa, which was the highest BR in comparison to the dehydrated alfalfa substrate, with $32 \%$ and bean straw with $46 \%$ (Table 5).

The mean temperature inside the incubation area of the production units was $22.1{ }^{\circ} \mathrm{C}$ (minimum) and $28.16{ }^{\circ} \mathrm{C}$ (maximum) during the months of February to May, which was the period in which the production units remained inside the incubation area. Mora (2004) reported a weekly mean temperature of $20.3{ }^{\circ} \mathrm{C}$ to $27.7^{\circ} \mathrm{C}$, with a maximum of 27.2 and a minimum of $20.0{ }^{\circ} \mathrm{C}$, and Gómez (2004) reported values that range from $23^{\circ} \mathrm{C}$ to $26.7^{\circ} \mathrm{C}$ for the months of April to May, similar to those reported in this study. Regarding the fructification area, the mean temperature ranged between $18.4^{\circ} \mathrm{C}$ (minimum) and $25.5{ }^{\circ} \mathrm{C}$ (maximum) during the months of June to September, where the last harvests were obtained. Gómez (2004) reported a mean temperature between 21 and $23.9^{\circ} \mathrm{C}$ for the weeks of June to July; in addition, a relative humidity that ranged between 76.5 to $87.3 \%$ for the months of May to June, similar results to those of this study, where the average relative humidity in the rustic module of production within the fructification area was $78.3 \%$. It should be mentioned that the

Cuadro 5. Tasa de Biodegradación (TB).

Table 5. Biodegradation rate (BR).

TB (\%)

\begin{tabular}{lcccc}
\multicolumn{1}{c}{ Sustratos agrícolas } & TB \% Testigos & \multicolumn{3}{c}{ Suplementación de alfalfa deshidratada } \\
\cline { 3 - 5 } & & 2.0 & 2.5 & 3.0 \\
\hline Paja de trigo & $64 \mathrm{a}$ & $66 \mathrm{a}$ & $62 \mathrm{a}$ & $70 \mathrm{a}$ \\
Paja de cebada & $58 \mathrm{~b}$ & $60 \mathrm{a}$ & $56 \mathrm{~b}$ & $64 \mathrm{a}$ \\
Rastrojo de maíz & $52 \mathrm{~b}$ & $54 \mathrm{ba}$ & $50 \mathrm{~b}$ & $60 \mathrm{ab}$ \\
Pajilla de frijol & $46 \mathrm{c}$ & $48 \mathrm{~b}$ & $68 \mathrm{a}$ & $52 \mathrm{~b}$ \\
Alfalfa deshidratada & $32 \mathrm{~d}$ & & & \multirow{2}{*}{} \\
\hline
\end{tabular}

TB \%: porcentaje de tasa de biodegradación. *Medias con letras diferentes indican diferencias significativas con la prueba de Tukey $(\mathrm{P} \leq 0.05) . * \mathrm{~TB} \%$ : percentage of biodegradation rate. ${ }^{*}$ Means with different letters indicate significant differences with the Tukey test $(\mathrm{P} \leq 0.05)$. 


\section{Análisis químico proximal de sustratos}

Los sustratos utilizados en este experimento presentaron una composición química diferente (Cuadro 6). Estas diferencias hacen que la capacidad productiva de la cepa CP-50 de P. ostreatus obtenga mayores rendimientos en sustratos ricos en materia seca, como es el caso de paja de trigo, que presenta una concentración de $90.10 \%$; proteína cruda, $3.34 \%$; de extracto etéreo, $0.22 \%$; de cenizas, $11.34 \%$; FND, $85 \%$; y FAD, $51.14 \%$. Olavarría (2000) reporta valores de $1.7 \%$ de cenizas para la paja de ceba$\mathrm{da}$, que son inferiores a los encontrados en esta investigación. Asimismo, Beare et al. (2002) encuentran $13.58 \%$ de cenizas por cada 100 gramos de sustrato seco en rastrojo de maíz, valores superiores a los reportados en esta investigación. Yumi y Duchi (2007) reportan $2.5 \%$ de proteína en rastrojo de maíz, resultados inferiores en esta investigación $(4.9 \%$ de proteína sin suplementar con alfalfa deshidratada y $8.93 \%$ de proteína cruda al ser suplementada con alfalfa deshidratada). Rivas (2005) menciona que la alfalfa contiene alrededor de $50 \%$ de proteína cruda en la pared celular, así como una composición de fibra equilibrada, $8 \%$ de pectinas, $10 \%$ de hemicelulosas, $25 \%$ de celulosa, y $7 \%$ de lignina, lo cual favorece al desarrollo de los esporomas de las setas.

Urbano y Dávila (2003) comentan que el aporte de proteína cruda es significativo; la alfalfa presenta alrededor de $25 \%$ de nitrógeno no proteico, altamente soluble y asimilable para los hongos saprofitos, temperatures of incubation and fructification that were present in the production module had higher values than those reported by Mora (2004) and Gómez (2004), due to the environmental conditions of location.

\section{Proximal chemical analysis of substrates}

The substrates used in this experiment presented a different chemical composition (Table 6). These differences make the productive capacity of the P. ostreatus CP-50 strain obtain higher yields in substrates rich in dry matter, such as the case of wheat hay, which presents a concentration of $90.10 \%$; raw protein, $3.34 \%$; ethereal extract, $0.22 \%$; ashes, $11.34 \%$; NDF, $85 \%$; and ADF, $51.14 \%$. Olavarría (2000) reports values of $1.7 \%$ of ashes for barley hay, which are lower than those found in this study. Likewise, Beare et al. (2002) found $13.58 \%$ of ashes for every 100 grams of dry substrate in maize stubble, values higher than those reported in this study. Yumi and Duchi (2007) report $2.5 \%$ of protein in maize stubble, results that are lower in this study $(4.9 \%$ of protein without supplementing with dehydrated alfalfa and $8.93 \%$ of raw protein when being supplemented with dehydrated alfalfa). Rivas (2005) mentions that alfalfa contains around $50 \%$ of raw protein in the cell wall, as well as a balanced fiber composition, $8 \%$ of pectin, $10 \%$ of hemicellulose, $25 \%$ of cellulose, and $7 \%$ of lignin, which favors the development of sporocarps of the oyster mushrooms.

Cuadro 6. Resultados del Análisis Bromatológico de los sustratos empleados en la producción de la CP-50 de P. ostreatus. Table 6. Results of the Food Science Analysis of the substrates used in the production of P. ostreatus CP-50.

\begin{tabular}{|c|c|c|c|c|c|c|c|c|c|c|c|c|}
\hline \multirow{3}{*}{ Sustratos } & \multicolumn{12}{|c|}{$\%$} \\
\hline & \multicolumn{2}{|c|}{ MS } & \multicolumn{2}{|c|}{ PC } & \multicolumn{2}{|c|}{ EE } & \multicolumn{2}{|c|}{ Cenizas } & \multicolumn{2}{|c|}{ FND } & \multicolumn{2}{|c|}{ FAD } \\
\hline & S/Al & $\mathrm{C} / \mathrm{Al}$ & S/Al & $\mathrm{C} / \mathrm{Al}$ & S/Al & $\mathrm{C} / \mathrm{Al}$ & S/Al & $\mathrm{C} / \mathrm{Al}$ & S/Al & $\mathrm{C} / \mathrm{Al}$ & S/Al & $\mathrm{C} / \mathrm{Al}$ \\
\hline PT & 90.10 & 98.45 & 3.34 & 7.12 & 0.22 & 0.67 & 11.04 & 14.02 & 85.0 & 92.04 & 51.14 & 58.67 \\
\hline PC & 87.60 & 93,54 & 5.81 & 9.08 & 1.60 & 1.87 & 14.52 & 17.03 & 42.3 & 58.01 & 30.68 & 34.12 \\
\hline $\mathrm{RM}$ & 93.82 & 98.35 & 4.90 & 8.93 & 1.23 & 1.64 & 6.83 & 9.05 & 72.45 & 89.02 & 46.75 & 49.31 \\
\hline PF & 92.10 & 96.56 & 6.30 & 10.20 & 1.55 & 1.78 & 6.71 & 8.79 & 42.6 & 48.5 & 24.63 & 27.03 \\
\hline $\mathrm{AL}$ & \multicolumn{2}{|c|}{21.90} & \multicolumn{2}{|c|}{12.51} & \multicolumn{2}{|c|}{2.13} & \multicolumn{2}{|c|}{9.08} & \multicolumn{2}{|c|}{34} & \multicolumn{2}{|c|}{27} \\
\hline
\end{tabular}

PT: Paja de Trigo, PC: Paja de Cebada, RM: Rastrojo de Maíz, PF: Pajilla de Frijol, AL: Alfalfa Deshidratada, *S/AL: Sin Alfalfa, C/ Al: Con alfalfa Deshidratada (3 kg), M.S: Materia Seca, P.C: Proteína Cruda, E.E: Extracto Etéreo, FND: Fibra Neutro Detergente y FAD: Fibra Ácido Detergente. \& PT: Wheat Hay, PC: Barley Hay, RM: Maize Stubble, PF: Bean Straw, AL: Dehydrated Alfalfa, *S/ AL: Without Alfalfa, C/Al: With Dehydrated Alfalfa $(3 \mathrm{~kg})$, M.S: Dry Matter, P.C: Raw Protein, E.E: Ethereal Extract, FND: Neutral Detergent Fiber and FAD: Acid Detergent Fiber. 
como lo demuestra Danciang (1986), que estudió la productividad de $P$. ostreatus en paja de arroz y en aserrín, donde encontró que el primer sustrato produce un mayor número de carpóforos y de mayor diámetro que los desarrollados en aserrín. La diferencia en la productividad de estos sustratos puede deberse a las diferencias de proteína cruda $(15.10 \%)$ y de grasa $(0.35 \%)$ para la paja de arroz, contra $3.2 \%$ de proteína cruda y $0.14 \%$ de grasa para el aserrín. Además, Faner (2001) menciona que la alfalfa es una buena fuente de macrominerales (calcio, fósforo, magnesio, potasio, cloro), microminerales (zinc, cobre, hierro) vitaminas (liposolubles, grupo B) y pigmentos.

Las setas requieren sustratos con alta cantidad de nutrientes; en este sentido, Amuneke et al. (2011) obtiene $95 \%$ de fructificaciones en sustratos ricos en proteína. El incremento en la proteína bruta en los sustratos indica que el $P$. ostreatus tiene una alta capacidad de síntesis, desarrollándose mejor (Sudiany et al., 2012).

En este trabajo de investigación el rastrojo de maíz presentó una concentración de materia seca de $93.82 \%$. Al ser complementando con alfalfa deshidratada $(3.0 \mathrm{~kg})$ se vio un incremento en la EB, TP y TB, ya que aumentó su contenido de materia seca al $98.35 \%$; proteína cruda, de 4.90 a $8.93 \%$; extracto etéreo, 1.23 a $1.64 \%$; cenizas, 6.83 a $9.05 \%$; FND, 72.45 a $89.02 \%$; y FAD, 46.75 a $49.31 \%$, convirtiéndolo de un sustrato de bajo rendimiento a un sustrato de alto rendimiento en la producción de setas. Además, su disponibilidad en las zonas rurales del Municipio de Tetela de Ocampo, Puebla favorece su producción.

Cabe aclarar que las cifras presentadas anteriormente son valores promedio de los sustratos provenientes del Municipio de Tetela de Ocampo, Puebla, pero existe una amplia variación para el análisis químico proximal; por ejemplo, la proteína en la fibra de cebada varía de 3.9 a $8.7 \%$; en la de trigo, de 2.4 a $5.8 \%$; en la del rastrojo, de maíz de 2.0 a $7.1 \%$; y en la pajilla de frijol, de 6.0 a $7.9 \%$. La variación proviene principalmente del tipo de planta, aunque también son importantes otros factores como la variedad, el grado de madurez, el manejo, la fertilidad del suelo, la época de siembra, la ocurrencia de heladas, etcétera, que influyen en el desarrollo general de las plantas y, en consecuencia, en la constitución nutrimental de ellas (Romero-Arenas et al., 2010).
Urbano and Dávila (2003) mention that the raw protein contribution is significant; alfalfa presents around $25 \%$ of non-protein nitrogen, highly soluble and assimilable for saprophyte mushrooms, as shown by Danciang (1986), who studied the productivity of $P$. ostreatus in rice hay and sawdust, where they found that the first substrate produces a higher number of carpophores and of higher diameter than the ones developed in sawdust. The difference in the productivity of these substrates can be due to the differences in raw protein $(15.10 \%)$ and fat $(0.35 \%)$ for rice hay, versus $3.2 \%$ of raw protein and $0.14 \%$ of fat for the sawdust. In addition, Faner (2001) mentions that alfalfa is a good source of macrominerals (calcium, phosphorus, magnesium, potassium, chlorine), microminerals (zinc, copper, iron), vitamins (liposoluble, group B), and pigments.

Oyster mushrooms require substrates with a high amount of nutrients; in this sense, Amuneke et al. (2011) obtain $95 \%$ of fructifications in substrates rich in protein. The increase in raw protein in the substrates indicates that $P$. ostreatus has a high capacity for synthesis, developing better (Sudiany et al., 2012).

In this research study, maize stubble presented a dry matter concentration of $93.82 \%$. When complemented with dehydrated alfalfa $(3.0 \mathrm{~kg})$, an increase in BE, PR and BR was found, since its content of dry matter increased to $98.35 \%$; raw protein, from 4.90 to $8.93 \%$; ethereal extract, 1.23 to $1.64 \%$; ashes, 6.83 to $9.05 \%$; NDF, 72.45 to $89.02 \%$; and $\mathrm{ADF}, 46.75$ to $49.31 \%$, turning it from a low-yield substrate to a high-yield substrate in the production of oyster mushrooms. In addition, its availability in rural zones of the municipality of Tetela de Ocampo, Puebla, favors its production.

It should be clarified that the figures presented before are average values of the substrates from the municipality of Tetela de Ocampo, Puebla, but there is broad variation for the proximal chemical analysis; for example, the protein in barley fiber varied from 3.9 to $8.7 \%$; in wheat, from 2.4 to $5.8 \%$; in maize stubble, from 2.0 to $7.1 \%$; and in bean straw, from 6.0 to $7.9 \%$. The variation comes primarily from the type of plant, although other factors are also important such as the variety, the degree of maturity, management, soil fertility, sowing season, frost events, etc., which influence the general development of plants and, consequently, their nutritional constitution (Romero-Arenas et al., 2010). 


\section{Conclusiones}

La producción de la cepa CP-50 de P. ostreatus duró 121 días, donde la mayor producción en peso fresco se obtuvo con el tratamiento PT-3Al, que corresponde a paja de trigo suplementada con $3 \mathrm{~kg}$ de alfalfa deshidratada, con $17.94 \mathrm{~kg}$. La segunda la presentó el tratamiento PT-2.5Al, el cual corresponde a paja de trigo suplementada con $2.5 \mathrm{~kg}$ de alfalfa deshidratada. La tercera estuvo en el tratamiento PC-2.5Al, que corresponde a la paja de cebada suplementada con $2.5 \mathrm{~kg}$ de alfalfa deshidratada, en tanto que la producción más baja la registró el tratamiento "Alfalfa deshidratada", con un peso de $3.51 \mathrm{~kg}$.

La utilización de alfalfa deshidratada (Medicago sativa L.) como suplemento en los sustratos convencionales de Tetela de Ocampo, Puebla aumenta la eficiencia biológica EB y la tasa de biodegradación TB de la cepa CP-50 de P. ostreatus. Además, obtuvo un excelente desarrollo en el sustrato de rastrojo de maíz suplementado con 2.5 y $3.0 \mathrm{~kg}$ de alfalfa deshidratada, obteniendo EB hasta $120.91 \%$. De esta manera, se pueden aprovechar residuos producidos localmente para la producción de setas.

Por último, las condiciones controladas de las instalaciones donde se llevó a cabo el proceso de incubación y cosecha son importantes para el cultivo, conservando una temperatura ambiente de $26 \pm 2{ }^{\circ} \mathrm{C}$, una humedad entre 70 y $80 \%$ para el buen desarrollo de los cuerpos fructiferos y extracción de aire por $1 \mathrm{~h}$, cada $8 \mathrm{~h}$; estas consideraciones en la producción de setas influyen directamente en el desarrollo y calidad de los esporomas.

\section{Agradecimientos}

Los autores agradecen a la Vicerrectora de Investigación y Estudios de Posgrado de la Benemérita Universidad Autónoma de Puebla (BUAP). Asimismo, al Centro de Agroecología del Instituto de CienciasBUAP por el apoyo del financiamiento a este proyecto de investigación.

\section{Literatura Citada}

A.O.A.C. (Association of Official Analytical Chemists) 1980. Official methods of analysis of association of official agricultural chemist. 13th ed. Washington, D. C. 978 p.

Adebayo, E. A., D. Martinez-Carrera. 2015. Oyster mushroom (Pleurotus) are useful for utilizing lignocel- lulosic biomass.

\section{Conclusions}

The production of the P. ostreatus CP-50 strain lasted 121 days, where the highest production in fresh weight was obtained with the PT-3Al treatment, which corresponds to wheat hay supplemented with $3 \mathrm{~kg}$ of dehydrated alfalfa, with $17.94 \mathrm{~kg}$. The second was shown by PT-2.5Al, which corresponds to wheat hay supplemented with $2.5 \mathrm{~kg}$ of dehydrated alfalfa. The third was the treatment PC-2.5Al, which corresponds to barley hay supplemented with $2.5 \mathrm{~kg}$ of dehydrated alfalfa, while the lowest production was found in the "Dehydrated alfalfa" treatment, with a weight of $3.51 \mathrm{~kg}$.

The use of dehydrated alfalfa (Medicago sativa L.) as supplement in conventional substrates from Tetela de Ocampo, Puebla, increased the biological efficiency $\mathrm{BE}$ and biodegradation rate $\mathrm{BR}$ of the $\mathrm{CP}$ 50 strain of $P$. ostreatus. In addition, it obtained an excellent development in the maize stubble substrate supplemented with 2.5 and $3.0 \mathrm{~kg}$ of dehydrated alfalfa, obtaining a BE of up to $120.91 \%$. Thus, locally-produced residues can be used for oyster mushroom production.

Lastly, the controlled conditions of facilities where the incubation and harvest process were carried out are important for the crop, conserving a room temperature of $26 \pm 2{ }^{\circ} \mathrm{C}$, moisture between 70 and $80 \%$ for the good development of fructifying bodies and air extraction for $1 \mathrm{~h}$, every 8 $\mathrm{h}$; these considerations in the production of oyster mushrooms influence directly the development and quality of sporocarps.

$$
\text { - End of the English version - }
$$

Review African Journal of Biotechnology. 14(1): 52-67.

Aguirre, H. 2000. Aislamiento y caracterización de cepas de Pleurotus spp. nativas de Morelos y su cultivo en cuatro substratos. Tesis de Licenciatura, UAEM.

Akinyele, B., J. Fakoy., and C. Adetuyi. 2012. Anti-Growth Factors Associated with Pleurotus ostreatus in a Submerged Liquid Fermentation. Malaysian Journal of Microbiology. 8(3): $135-140$

Amuneke, E. H., K.S. Dike., and J. N. Ogbulie. 2011. Cultivation of Pleurotus ostreatus: An edible mushroom from agro base waste products. Microbiol. Biotech. Res. 1(3):1-14.

Andrino, A., A. Morte., y M. Honrubia. 2011. Caracterización y cultivo de tres cepas de Pleurotus eryngii (Fries) Quélet sobre sustratos basados en residuos agroalimentarios. Anales de 
Biología. 33(1): 53-66.

Beare, M., P. Wilson., P. Fraser., and R. Butler. 2002. Management effects on barley straw decomposition, nitrogen release, and crop production. Soil Science Society of American Journal. 66(1): 848-856.

Buswell, A. J., J. Cai., and S. T. Chang. 1993. Fungal and substrate associated factors affecting the ability of individual mushroom species to utilize different lignocellulosic growth substrates. In: S.T. Chang, J.A. Buswell, S.W. Chiu (eds). Mushroom biology and mushroom products. The Chinese University Press, Hong Kong. pp: 141-150.

Cedano, M., M. Martínez., C. Soto-Velazco., and L. GuzmánDávalos. 1993. Pleurotus ostreatoroseus (Basidiomycotina, Agaricales) in México and its growth in agroindustrial wastes. Cryp. Bot. 3: 397-302.

Chang, S.T., and S. P. Wasser. 2012. The role of culinary medicinal mushrooms on human welfare with a pyramid model for human health. Int J Med Mushrooms. 1: 95-134.

Cunha, Z. D., and G. A. Pardo. 2017. Edible and Medicinal Mushrooms: Technology and Applications. Ed. John Wiley \& Sons Ltd. U.S.A. 592 p.

Danciang, C. 1986. Culture of oyster mushroom (Pleurotus ostreatus Florida) on five farms wastes at different levels of ammonium sulfate. Scientific Journal. 6(1): 64.

Enciclopedia de los municipios de Puebla 2013. Sistema estatal y municipal de base de datos. (Consulta: Julio 2016). http://sc.inegi.org.mx/sistemas/cobdem/contenido. jsp?rf=false\&solicitud $=$

Fanadzo, M., D. T. Zireva., E. Dube, and A. B. Mashingaidze. 2010. Evaluation of various substrates and supplements for biological efficiency of Pleurotus sajor-caju and Pleurotus ostreatus. African Journal of Biotechnology. 19: 2756-2761.

Faner, C. 2001. Utilización de la pastura en alimentación porcina. Memoria de Fericedo. EEA INTA. México. pp: 2-7.

Flores, R. G. 2012. Aprovechamiento del bagazo residual de Yucca spp. como sustrato para la producción de Pleurotus spp. Tesis de Maestría. Unidad Profesional Interdisciplinaria de Biotecnología. Instituto Politécnico Nacional. México. 111 p.

FAO (Food and Agriculture Organization of the United Nations). 2014. Available online: http://faostat.fao.org/ site/567/DesktopDefault.aspx?PageID=567\#ancor (acesado el 10 de abril de 2016).

Franco, W. J. 1990. Métodos de análisis utilizados para la evaluación de proteína. CINVESTAV-IPN. México, D.F.

Gaitán-Hernández, R., P. Salmones., P. Dulce., R. Merlo., y G. Mata. 2009. Evaluación de la eficiencia biológica de cepas de Pleurotus pulmonarius en paja de cebada fermentada. Revista mexicana de micología. 30: 63-71.

Garzón, G., J. P. Leonardo., y C. Andrade. 2008. Producción de Pleurotus ostreatus sobre residuos sólidos lignocelulósicos de diferente procedencia. NOVA. 6(10): 101-236.

Gómez, A. 2004. Evaluación de la eficiencia biológica de dos cepas comerciales de Pleurotus ostreatus con relación al tamańo de bolsa sobre paja de trigo. Morelos, México. Tesis de Licenciatura, UAEM.

Kumari, D., V. Achal. 2008. Effect of different substrates on the production and nonenzymatic antioxidant activity of Pleurotus ostreatus (Oyster mushroom). Life Sciences Journal. 5: 73-76.

López, C., E. H. Ancona., y P. S. Medina. 2005. Cultivo de Pleu- rotus djamor en laboratorio y en una casa rural tropical. Revista Mexicana de Micología. 21: 93-97.

López, R., C. Hernández., C. R. Suárez., y F. C. Borrero. 2008. Evaluación del crecimiento y producción de Pleurotus ostreatus sobre diferentes residuos agroindustriales. Universitas Scientiarum. 13(2): 128-137.

Mane, V. P., S. S. Patil., A. A. Syed., and M. V. Baig. 2007. Bioconversion of low quality lignocellulosic agricultural waste into edible protein by Pleurotus sajor-caju (Fr.) Singer. J Zhejiang Univ Sci B. 8(10): 745-51.

Martínez-Carrera, D., A. Larqué-Saavedra., A. Tovar-Palacio., N. Torres., M. E. Meneses., M. Sobal-Cruz., P. MoralesAlmora., M. Bonilla-Quintero., U. H. Escudero., I. TelloSalgado., T. Bernabé-González., W. Martínez-Sánchez., e Y. Mayett. 2016. Contribución de los hongos comestibles funcionales y medicinales a la construcción de un paradigma sobre la producción, la dieta, la salud y la cultura en el sistema agroalimentario de México. In: Martínez-Carrera D., J. Ramírez Juárez (eds); Ciencia, tecnología e innovación en el sistema agroalimentario de México. Editorial del Colegio de Postgraduados-AMC-CONACYT-UPAEP-IMINAP, San Luis Huexotla, Texcoco, México, pp: 581-640.

Martínez-Carrera, D., P. Morales., M. Sobal., M. Bonilla., W. Martínez., e Y. Mayett. 2012. Los hongos comestibles, funcionales y medicinales: su contribución al desarrollo de las cadenas agroalimentarias y la seguridad alimentaria en México. In: Memorias Reunión General de la Academia Mexicana de Ciencias: Ciencia y Humanismo (Agrociencias). Academia Mexicana de Ciencias, México, D.F. pp: 449-474.

Martínez-Carrera, D., P. Morales., M. Sobal, M. Bonilla., y W. Martínez. 2007. México ante la globalización en el siglo XXI: el sistema de producción consumo de los hongos comestibles. Capítulo 6.1, 20 p.

Medel, R., T. Espinosa., A. Sánchez., O. Romero-Arenas., y L. Reyes. 2011. Diversidad de Hongos Capítulo 4. Biodiversidad de Puebla Estudio de Estado. Edición: BUAP, CONABIO y Gobierno del estado de Puebla. ISBN: 978-6077607-54-0. Puebla, México. 409 p.

Mora, V. 2004. Estudio comparativo de diferentes cepas comerciales que se cultivan en México de Pleurotus spp. Tesis de Maestría. UNAM.

Mora, V., y D. Martínez-Carrera. 2007. Investigaciones básicas, aplicadas y socioeconómicas sobre el cultivo de setas (Pleurotus) en México. Capítulo 1.1. In: El Cultivo de Setas Pleurotus spp. en México. J.E. Sánchez., D. Martínez-Carrera., G. Mata., H. Leal (eds). ECOSUR-CONACYT. ISBN 978970-9712-40-7.b. México, D.F. 230 p.

Rajak, S., S. C. Mahapatra., and M. Basu. 2011. Yield, Fruit Body Diameter and Cropping Duration of Oyster Mushroom (Pleurotus sajor caju) Grown on Different Grasses and Paddy Straw as Substrates. Eur. J. Med. Plants. 1: 10-17.

Reyes, G.R., A.E., Abella, F., EguchI, T., Iijima, M., Higaki, and T.H., Quimio. 2004. Growing paddy straw mushroom. In: Mushroom grower's handbook; Oyster mushroom cultivation. Mushroom World. Corea. pp: 262-269.

Rivas, J. M. A., C. C. López., G. A. Hernández., y P. J. Pérez. 2005. Efecto de tres regímenes de cosecha en el comportamiento productivo de cinco variedades comerciales de alfalfa (Medicago sativa L.). Téc Pecu Méx. 43(1): 79-92.

Romero-Arenas, O., M. Huerta., M. A. Damián., A. Macías., J. 
A. Rivera., F. C. Parraguirre., y J. Huerta. 2010. Evaluación de la capacidad productiva de Pleurotus ostreatus con el uso de hoja de plátano (Musa paradisiaca L., cv. Roatan) deshidratada, en relación con otros sustratos agrícolas. Agronomía Costarricense. 34(1): 53-63.

Romero-Arenas, O., M. A. Martínez., M. A. Damián., B. Ramírez., y J. López-Olguín. 2015. Producción de hongo Shiitake (Lentinula edodes Pegler) en bloques sintéticos utilizando residuos agroforestales. Revista Mexicana de Ciencias Agrícolas. 6(6): 1229-1238.

Royse, D. J., J. Baars., and Q. Tan. 2016. Current overview of mushroom production in the world. In: Zied DC, editor. Edible and medicinal mushrooms: technology and applications. New York, Wiley. 462 p.
SAGARPA-SIAP (Secretaría de Agricultura, Ganadería, Desarrollo Rural, Pesca y Alimentación-Servicio de Información Alimentaria y Pesquera). 2015. Situación actual y perspectivas de alfalfa verde en México 2010-2015. Consultado el 01/09/2017 en http://infosiap.siap.gob.mx/aagricola_siap_ $\mathrm{gb} /$ icultivo/index.jsp.

Salmones, D., H. R. Gaytán., R. Pérez., y G. Guzmán. 1997. Estudios sobre el género Pleurotus VIII, Interacción entre crecimiento micelial y productividad. Rev. Iberoam Micol. 14: $173-176$

Sobal, M., D. Martínez-Carrera., P. Morales., and S. Roussos. 2007. Classical characterization of mushroom genetic resources from temperate and tropical regions of Mexico. Micología Aplicada International. 19(1): 15-23. 